\title{
Medicare and the care of First Nations, Métis and Inuit
}

\author{
JOSÉE G. LAVOIE* \\ Professor, Department of Community Health Sciences and Director, University of Manitoba, Canada \\ Ongomiizwin Research, University of Manitoba, Canada
}

\begin{abstract}
The Canada Health Act 1984 (CHA) is considered foundational to Canada's publicly funded health care system (known as Medicare). The CHA provides for the federal transfer of funding to the provinces/territories, in exchange for provincial/territorial adherence to Medicare's key principles of universality; comprehensiveness; portability; accessibility; and, public administration. Medicare is a decentralized health care system, managed independently by Canada's 10 provincial and three territorial governments, allowing for regional adaptations to fit varying degrees of urbanity, remoteness and needs. The Act is silent on its relationship to the Indigenous health care system - what some have described as Canada's 14th health care system. The CHA has not kept pace with Indigenous self-government activities that have since spread across Canada. It has unfortunately crystallized the federal/provincial/territorial/Indigenous jurisdictional fragmentation that perpetuates health inequities and has failed to clarify these jurisdictions' obligations towards Indigenous peoples. As a result of these omissions, access to health services remains a concern for many Indigenous Canadians, resulting in poorer outcomes and premature mortality. In this paper, I argue that Medicare renewal must: make an explicit commitment to Indigenous health equity; clarify jurisdictional obligations; establish effective mechanisms for addressing areas of jurisdictional dispute and/or confusion; and explicitly recognize First Nations and Inuit health care services as integral yet distinct systems, that nevertheless must be welcomed to seamlessly work with provincial health care systems to ensure continuity of care.
\end{abstract}

Submitted 1 April 2017; revised 19 May 2017; accepted 1 July 2017; first published online 1 February 2018

\footnotetext{
*Correspondence to: Professor Josée G. Lavoie, Department of Community Health Sciences and Director, University of Manitoba, Ongomiizwin Research, \#715, 727 McDermot Avenue, Winnipeg, Manitoba, R3E 3P4, Canada. Email: Josee.Lavoie@umanitoba.ca
} 


\section{Introduction}

In 2004, Tommy Douglas was named the Greatest Canadian of all time for his social democratic legacy, ${ }^{1}$ which led to the creation of the iconic Canadian public health care system, commonly known as Medicare. While the genesis of Medicare is too complex to be attributed to a single individual (Stevenson et al., 1988), it is obvious that Douglas was a catalyst and key player. It was Douglas who, in 1947, led his government to introduce the first universal hospital insurance plan in North America, the Saskatchewan Hospital Services Plan.

Inspired by developments in Saskatchewan, the Canadian federal government implemented the Hospital Insurance and Diagnostic Services Act (HIDS) in 1957 and the Medical Care Act in 1966, which offered to reimburse participating provinces one-half of their hospital and diagnostic services, as well as medical costs administered under provincial health insurance programmes (Madore, 1991). In order to receive funding, coverage had to be universal, comprehensive, accessible and portable. The Canada Health Act 1984 (CHA) reiterated these four criteria, adding public administration as a fifth (Canada, 2004).

The CHA in fact created a nationally articulated health care system by linking and, to a limited extent, harmonizing the 10 provincial and more recently, three territorial health care systems, while allowing for considerable adaptation at the provincial and territorial levels. Notably excluded by the CHA and its predecessors is Canada's '14th health care system' (see Lavoie et al., 2016a for a detailed discussion). This $\$ 1.7$ billion system, ${ }^{2}$ funded by the federal government and overseen by the First Nations and Inuit Health Branch (FNIHB) of Health Canada, functions primarily in First Nations communities located in all provinces and the Yukon, and in Inuit communities located in Nunavik (Québec) and Nunatsiaq (Labrador), serving a population of $\sim 800,000$ peoples. A number of First Nation and Inuit communities in Labrador, Northern Québec, Manitoba and British Columbia have signed tripartite self-government agreements and are no longer funded through or overseen by FNIHB for their health services. As a result, funding flows directly to the Indigenous communities but to the extent that health care programmes are included as part of that transfer, the health care programmes funded under self-government agreements remain largely defined by FNIHB (see Lavoie et al., 2016a). For the purpose of this paper, I am including

1 Medicare is only one part of Douglas' legacy, which included the old age pension, family allowance, the 40-hour work week, the Saskatchewan Art Board (the first on the continent), the labour code, minimum wages, free textbooks in schools, unemployment insurance, the first Bill of rights (which preceded the UN's Bill of Rights by a decade) and many other accomplishments.

2 For scale, this budget is twice that of Canada's smallest provinces, Prince Edward Island (with $\sim 150,000$ residents); and reflect the budget of all three territories combined (120,000 residents). These comparisons should, however, be made with caution, as the 14th health care system fund a limited number of services focussed on prevention, health promotion, some primary care, as well as medical transportation, prescription drugs, dental care and eye care. Secondary and tertiary care are funded by the provinces/ territories in which the First Nation or Inuit individual reside. 
these services as part of my discussion of Canada's 14th health care system. For historical reasons, Métis health services are considered a matter of provincial jurisdiction (Lavoie et al., 2013).

The past decades of research and inquiries have highlighted continued Indigenous $^{3}$ health inequities related to differential access to health services, unresponsive care and racism (see Romanow, 2002; The Jordan's Principle Working Group, 2015; Lavoie et al., 2016a, 2016b, for examples). Canada's 14th health care system is unique in that it is entirely focussed on rural and remote First Nation and Inuit primary health care, with an emphasis on prevention. It has historically been systematically excluded from federal-provincial-territorial health system negotiations and also largely from political health discourse. In what follows, I discuss how this oversight happened, explore the resulting consequences, and recommend remedies. This paper begins with a discussion of the context that led to the creation of Medicare, focussing on how services to Indigenous Canadians were described and framed in historical documents. The next section explores the role of the federal government in the provision of services to Indigenous Canadians. This is followed by a discussion of contemporary Health Accord debates, and the consequences of allowing such little space to be given to the 14th health care system in these debates. Finally, I conclude with some thoughts on remedies to ameliorate this situation. Table 1 summarizes key events and reports cited in this paper.

Throughout this paper, I draw from historical and contemporary Indigenous health policy literature, complemented with a review of relevant primary documents. In addition, I draw from my observations garnered from nearly 30 years of working for Indigenous health organizations (First Nations, Inuit and Métis), first as a student, then as an employee or contractor, and more recently as a researcher and ally.

\section{The federal involvement in health care delivery}

\section{On bumanitarian grounds}

Historians have argued that federal engagement in health service delivery to First Nations and Inuit was initially a response to settlers' concerns that the deplorable health status of First Nations might threaten their own health (Weaver, 1971). As pointed out by Barron, "Indian misery was seldom attributed to ... neglect and racism" (1997: 61), which was rampant at the time, or to socio-economic deprivation enforced by federal policies and 'Indian Agents'4 (Titley, 2009).

3 In Canada, the collective term 'Aboriginal' is used in government documents as an umbrella term encompassing First Nations (previously known as Indians), Inuit and Métis, as entrenched in the 1982 Canadian Constitution. The term glosses over cultural, legislative and administrative complexities, and has been criticized by Indigenous health organizations for being a federal government's artefact. In this paper, the less problematic term Indigenous is preferred, and will be used only when statements apply to First Nations living on and off-reserve, Inuit, Métis and non-status individuals of First Nation ancestry. In other cases, self-referents will be used.

4 Federal administrators employed to manage local First Nation communities and enforce policies. 
Table 1. Historical milestones

\begin{tabular}{|c|c|c|c|c|}
\hline Years & $\begin{array}{l}\text { Historical } \\
\text { update }\end{array}$ & $\begin{array}{l}\text { Report/ } \\
\text { policy }\end{array}$ & Legislation & Description \\
\hline 1920 & $\sqrt{ }$ & & & Federal delivery of health services in Peguis First Nations, $\mathrm{MB}$ \\
\hline 1945 & $\sqrt{ }$ & & & $\begin{array}{l}\text { Federal Department of National Health and Welfare, } \\
\text { Directorate of Indian Health Services created }\end{array}$ \\
\hline 1947 & & & $\sqrt{ }$ & SK Hospital Services Plan \\
\hline 1954 & $\sqrt{ }$ & & & $\begin{array}{l}\text { The Directorate begins to assume some responsibilities for } \\
\text { funding health services for First Nations and Inuit in } \\
\text { NFLD \& Labrador }\end{array}$ \\
\hline Late $1950 \mathrm{~s}$ & $\sqrt{ }$ & & & $\begin{array}{l}\text { The Directorate of Indian Health Services operates } 22 \\
\text { hospitals, } 38 \text { nursing stations and more than } 100 \\
\text { health centres }\end{array}$ \\
\hline 1957 & & & $\sqrt{ }$ & Federal Hospital Insurance and Diagnostic Services Act \\
\hline 1966 & & & $\sqrt{ }$ & Federal Medical Care Act \\
\hline 1968 & & & $\sqrt{ }$ & Federal Health Plan for Indians \\
\hline 1969 & & $\sqrt{ }$ & & Booz Allen and Hamilton tasked to study the middle north \\
\hline 1979 & & $\sqrt{ }$ & & Indian Health Policy \\
\hline 1981 & & $\sqrt{ }$ & & Community Health Demonstration Programme \\
\hline 1982 & & & $\sqrt{ }$ & $\begin{array}{l}\text { Constitution Act recognizes Aboriginal peoples' inherent } \\
\text { right to self-government }\end{array}$ \\
\hline 1987 & & $\sqrt{ }$ & & Québec's Commission d'enquête \\
\hline 1988 & $\sqrt{ }$ & & & Devolution of health services to territorial governments \\
\hline 1989 & & $\sqrt{ }$ & & Alberta's Rainbow Report \\
\hline 1991 & & $\sqrt{ }$ & & British Columbia's Closer to home \\
\hline 1994 & & $\sqrt{ }$ & & New Directions: Aboriginal Health Policy for Ontario \\
\hline 1995 & & $\sqrt{ }$ & & Pathways to First Nation Control \\
\hline 1996 & & $\sqrt{ }$ & & Royal Commission on Aboriginal Peoples \\
\hline 1998 & & $\sqrt{ }$ & & Canada Health Action: Building on the Legacy \\
\hline 2000 & & $\sqrt{ }$ & & National Aboriginal Health Organization \\
\hline 2002 & & $\sqrt{ }$ & & Royal Commission on the Future of Health in Canada \\
\hline 2002 & & $\sqrt{ }$ & & $\begin{array}{l}\text { The Health of Canadians - The Federal Role (the Kirby } \\
\text { report) }\end{array}$ \\
\hline 2003 & & $\sqrt{ }$ & & $\begin{array}{l}\text { National Advisory Committee on SARS and Public } \\
\text { Health (the Naylor report) }\end{array}$ \\
\hline 2003 & & $\sqrt{ }$ & & First Ministers' Accord on Health Care Renewal \\
\hline 2004 & & $\sqrt{ }$ & & 10-Year Plan to Strengthen Health Care \\
\hline 2004 & $\sqrt{ }$ & & & $\begin{array}{l}\text { Tommy Douglas is declared the Greatest Canadian of all } \\
\text { times }\end{array}$ \\
\hline 2004 & & & $\sqrt{ }$ & Canada Health Act \\
\hline 2005 & & $\sqrt{ }$ & & Kelowna Accord \\
\hline 2005 & $\sqrt{ }$ & & & Aboriginal Health Transition Fund \\
\hline 2015 & & $\sqrt{ }$ & & Truth and Reconciliation Commission of Canada \\
\hline 2017 & & $\sqrt{ }$ & & New Health Accord negotiations \\
\hline
\end{tabular}

Note: NFLD $=$ Newfoundland.

The first federally managed clinic was opened on the Peguis First Nation in Manitoba in the 1920s. By the late 1950s, the Directorate of Indian Health Services (IHS), under the newly created Department of National Health and 
Welfare (NHW, created in 1945), ${ }^{5}$ operated 'a system of 22 hospitals, 38 nursing stations and more than 100 health centres staffed by medical officers or graduate nurses' (Brittain, 1959: 632). In addition, the Directorate worked with 700 other hospitals and 2200 physicians and dentists who billed the Directorate for services provided to eligible 'Indians' ${ }^{6}$ According to Brittain, then Assistant Director of the Directorate, the development of provincial health insurance plans throughout the 1950s 'produced no basic change in the role of Indian Health Services' (Brittain, 1959: 632), which he claimed continued to pay for services provided to 'Indians'. Evidence suggests, however, that the situation was murkier, with some First Nations being asked to cover costs out of pocket like their provincial counterparts (co-payments, e.g. see Boyer, 2014: 147-150; Lux, 2010 also provide examples). Further, it appears that when the Dominion of Newfoundland joined Canada in 1949, the last province to do so, the federal government made no provision to contribute to health services to First Nations and Inuit. This was partially rectified in 1954, when a plan was created to help pay for medical and other services, falling short of what was being provided to other Indigenous communities elsewhere in the country (Higgins, 2009).

The creation of Medicare added complexities and grey areas to previous arrangements providing federal coverage to select Indigenous peoples. While there were variations, it appears that the IHS continued to assume some coverage for First Nations and Inuit in most provinces, despite the federal adoption of the HIDS Act of 1957 and the Medical Care Act of 1966. These Acts committed the federal government to pay the provinces approximately half the cost of all insured health services, as long as the provinces provided universal coverage to all of their residents. Although it was the official IHS policy that IHS funding would cover costs only for 'Indians' who were also indigent, the policy proved unenforceable (Lux, 2016) and coverage continued to be extended to indigent and non-indigent 'Indians.'

In 1968, the IHS released the Health Plan for Indians, stating that the IHS would no longer subsidize the hospital and medical care of Indians. As the provinces gradually adopted the Medical Care Act 1966, Indians were expected to access services through their provincial plan, and personally take on the financial responsibility for co-payments and premiums, as any other citizen. If indigent,

5 For clarity, services for First Nations were provided/funded under a series of authorities, namely:

- the IHS of the Department of NHW (1945-1962);

- the Medical Services Branch, under the Department of NHW (1962-2000); and

- the FNIHB of Health Canada (2000-current).In this paper, I will use the name of the authority in place at the time.

6 The historical term 'Indians' can be defined as 'a registered member of a band, living in an Indian community, living the Indian way of life or living off the reserve but not qualified by residency for assistance' from a municipality (Brittain, 1959: 632). The term 'Indian' will only be used when quoting historical documents or when referring to the Indian Act's legal term 'Indians' which defines access to certain federal programs and benefits. 
they were expected to apply to the province for financial assistance with co-payments and premiums. Only if denied would the IHS consider some assistance. This may be understood as the birth of the payer of last resort principle, now entrenched in FNIHB's policies (Lavoie et al., 2015). IHS staff were directed to focus on prevention and education, and to continue to work to 'get out of the hospital business' (Lux, 2016: 130). In many ways, the Health Plan for Indians marked the end of an era where the federal government acknowledged some responsibility for IHS on humanitarian grounds, and the beginning of a new era, where obligations were to be defined only as complementary to those taken on by the provinces, and gradually pruned back. It also marked the beginning of a movement to transfer responsibility for the delivery of health services to First Nations, with funding from the federal government (Booz Allen \& Hamilton Canada Ltd, 1969). As a first step in that direction, First Nation communities were asked to develop a list of legitimate indigents, and police eligibility for IHS' support for their own members. This role was portrayed as a first step towards equality, but again proved unenforceable.

The election of Pierre Trudeau on 25 June 1968 and the nomination of John Munro as the new Minister of Health, marked a softening of policy language, and perhaps a more pragmatic approach. In 1969, the firm Booz Allen and Hamilton was tasked to study the health and health care needs of Indians in the 'middle north'. This was a term given to the northern regions of each province, the historical territory of many Indigenous communities, and of much younger and at times short-lived non-Indigenous communities fuelled by resource extraction economies (i.e. mining and logging). The impetus to study the 'middle north' was perhaps from a recognition that provincial health services tended to be located in larger urban and southern centres, leaving much of the 'middle north' with poorer access to provincial services (Booz Allen \& Hamilton Canada Ltd, 1969: 200). This focus on the 'middle north', however, aligned well with a longer-term agenda of offloading obligations onto the provinces. This desire was captured by the following quote in which, speaking to the need for new health facilities on-reserve, the consultants recommended,

[N]ew [health] facilities should be mobile. It is hoped that, in time, economic development will take place in the Middle North. With the resulting influx of population and increased economic vitality, [provincially-funded] resources for health care would be established, making permanent Indian facilities obsolete. In cases where economic development does not take place, it would be hoped that Indians would move to more economically viable areas and they should be encouraged to do so. If permanent facilities were constructed, their existence might discourage bands from relocating. If the band does relocate subsequent to the construction of a permanent facility, that facility would no longer be suitable (Booz Allen \& Hamilton Canada Ltd, 1969: 175).

Some communities in which I worked in the mid-1990s still used ageing and inadequate trailers for health facilities. 
Health services in the territories were managed directly by the federal government. This was the case until the adoption of the policy of devolution, which resulted in the establishment of the territorial Departments of Health tasked with managing the planning and delivery of territorial health services. This transfer was largely completed by the late 1980s (Dacks, 1990). It is noteworthy that although self-government agreements have been signed in the Northwest Territories and Nunavut, these did not include local control over health services. In contrast, some Yukon First Nations are managing a limited number of small prevention-oriented health programmes. The funding for these programmes is the same as for urban Indigenous organizations and access is on a competitive basis.

\section{The federal government's continued involvement}

Beginning in the 1970s, the focus of federal polices was two-fold: first, to gradually prune back the scope of its involvement in First Nations and Inuit health programmes while increasingly shifting responsibilities to the provinces; and second, to transfer the responsibility for the administration of existing residual programmes to First Nation and Inuit communities. Despite multiple unsuccessful attempts at shifting responsibilities to the provinces, by the 1970s, every First Nation community with sufficient membership ${ }^{7}$ had local access to federally funded health services delivered by nurses. These services were supplemented by the assistance of Community Health Representatives (CHRs), an innovation recommended by the Booz Allen and Hamilton report, and implemented in the 1970s. CHRs are local staff hired to support nurses with translation, planning clinics and cultural context (Waldram et al., 2006). Addiction prevention workers (under the National Native Alcohol and Drug Addictions programme) were also part of the team. Whereas the nursing staff were federal employees, the CHRs and Addiction Workers were community employees. Meanwhile the federal government's commitment to and investments in Indian hospitals were dwindling (Lux, 2016). By that time, every province operated services under the Medicare umbrella. Theoretically, First Nations and Inuit had access to all services provided under Medicare. In practice, however, access to services was constrained by remoteness, poor road access, economic barriers (related to co-payments and the cost of travel) and racism (Lux, 2016). Federal hospitals and other services, in contrast, operated outside of any legislative framework, except perhaps for the loosely worded Indian Act section 73(1)g, which gives the Government in Council the authority to 'provide medical treatment and health services for Indians' (Canada, 1985). This is still the case today.

Although Indigenous resistance to the erosion of the federal government's role in the provision of health care was prevalent and vocal through the years

7 Over the past two decades, I encountered very small isolated communities (sometimes as low as 20 residents) that did not have a local facility, but never encountered a policy stating the minimal population size required for FNIHB to provide some level of care, even if limited to visiting part time staff. 
(Brittain, 1959; Lux, 2016), the federal government's attempt, in 1978, to reduce the provision of services only to indigent First Nations (and presumably Inuit) prompted a nation-wide response, led by the newly formed National Indian Brotherhood (1972, now known as the Assembly of First Nations) who argued that Treaty rights were being abrogated (Auditor General of Canada, 1982). ${ }^{8}$ This reaction, which coincided with the 1979 election of Joe Clark, led to the adoption of the first Indian Health Policy. The two-page policy committed to restoring Indian health through community development, a reaffirmation of the traditional relationship of Indian peoples to the federal government, and by 'strengthening the relationships within the Canadian healthcare system.' This policy, however, was never supported by an implementation plan (Crombie, The Honourable David, 1979).

By then, opportunities for offering First Nations and Inuit some control over local health services were beginning to emerge through self-government agreements. For example, the James Bay and Northern Québec Agreement was signed by representatives of the James Bay Cree, the Inuit of Nunavik, and the federal and Québec governments, creating the first Cree and Inuit Boards of Health and Social Services in Canada (Canada, 1974). The same agreement also allowed for the clarification of federal and provincial responsibilities, but only for these communities.

Elsewhere, opportunities for Indigenous control of community-based health services were also growing. In 1981, the federal government initiated the Community Health Demonstration Programme in an attempt to assess the costs, timing and implications of future transfers of control of local health services to province-based First Nation and Inuit local community authorities (Bégin, The Honourable Monique, 1981). Since then, the majority of community-based health development in First Nations and Inuit communities south of the 60th parallel has occurred under the auspices of the 1989 Health Transfer Policy and its more recent iteration [Health Canada (FNIHB), 2008a], which evolved from the CDHP, with periodic refinements (Lavoie et al., 2005). The policy, managed by FNIHB, enables communities to assess their health needs and develop appropriate and responsive community health plans and programs. The allocated funding is largely based on historical expenditures, with some provisions made for administration (Lavoie et al., 2005). As of 2008 (the last time these reports were made public by FNIHB), $89 \%$ of eligible communities were engaged in some level of community/regional control over local services [Health Canada (FNIHB), 2008b].

The federal push to support First Nation and Inuit control over health services was undeniably linked to a long-standing agenda of getting out of the business of

8 I purposely side-step the debate over the treaty right to health care, which is founded on provisions included in Treaty 6, and discussed in the negotiations of treaties 8,10 and 11, but not included in the final texts. While the argument is a valid one, and likely to be settled in future Supreme Court decisions, my purpose in this paper was to focus on federal policies and practices. To date, the federal government denies that a treaty right to health care exists. For detailed analyses, please see Boyer $(2004,2014)$. 
health service delivery altogether. The vision expressed in the 1995 Pathways to First Nation Control document, a vision described by FNIHB employees as 'turning off the lights' because it intended to eliminate or greatly limit the need for a federal agency, turned out to be unrealistic [Health Canada (MSB), 1995]. It soon became clear that FNIHB was to retain a role, even in a post-transfer environment. More precisely, FNIHB would: remain responsible and accountable for the overall performance of the on-reserve primary health care system for First Nations and Inuit; exercise an oversight role over its programmes; and finally, monitor services delivered on-reserve to ensure that they meet standards of quality and that the public health and safety of communities are protected (Lavoie et al., 2005).

Progressive disinvestments by FNIHB nevertheless continued. Examples include the demise of the FNIHB dental programme, the on-going erosion of the prescription drug formulary, and capped funding for on-reserve health services. Collectively, the result has been declining per capita health care expenditures at a time when communities are managing more and more complex health care needs (Lavoie et al., 2005, 2015; Lavoie, 2016). These disinvestments in prevention and early intervention programmes are likely to contribute to the disproportionate rates of preventable hospitalization documented for First Nations and Inuit (Shah et al., 2003; Lavoie et al., 2010; British Columbia Provincial Health Officer, 2009; Carrière et al., 2016). Hospital costs are shouldered by the provinces (Lavoie et al., 2010).

The most recent and ground-breaking iteration of community control is the wholesale transfer of FNIHB's regional responsibilities to a First Nation Health Authority (FNHA) in British Columbia in October 2013. While the FNHA is creating unprecedented opportunities for First Nations to redefine on-reserve health services and their relationship to provincial services (Kelly, 2011), it also marks a sizable federal government retreat and an increased formal engagement of the province through the Tripartite Agreement (First Nations Health Council, Government of Canada, and Government of British Columbia, 2010). Still, FNIHB remains the primary funder of the FNHA (4.7B \$ from 2012-2013 to 2022-2023; Auditor General of Canada, 2015), and retains continued responsibilities, which are itemized in the Tripartite Agreement (First Nations Health Council, Government of Canada, and Government of British Columbia, 2010).

Overall and despite continued pruning attempts, the federal government's responsibility for oversight will remain because of its substantial financial contribution, for which it remains accountable. While the FNHA has gained substantial autonomy from regional FNIHB decision-making processes (Gallagher et al., 2015; O'Neil et al., 2016), it remains accountable, albeit in a less micro-managed way, to FNIHB.

\section{The CHA, health accords and Indigenous' health}

The CHA, introduced by Monique Bégin in 1984, replaced previous legislation, and discouraged extra-billing and user fees. It was framed primarily as a mechanism to 
transfer funding to eligible provinces (those abiding to the five main principles listed in the introduction). Through the 1980s, Canadians reported a very high level of satisfaction with their health care system, when compared with Great Britain or the United States. By the 1990s, an economic downturn, higher unemployment, a growing federal deficit and reduced growth in the transfer of payments to the provinces (beginning as early as 1986), increased pressure on systems and created an impetus to realign services and innovate to ensure sustainability.

In answer to growing discontent and pressures, most provinces conducted extensive reviews of their health care systems. In their review of these documents, Mhatre and Deber (1992) noted recurring themes, including: engaging the collaboration of multiple sectors in addressing determinants of health; shifting emphasis to promoting health and preventing disease; switching focus to community-based care; increasing opportunities for individual participation in health choices and policies; devolution or decentralization of the provincial systems; improved human resources planning; enhanced efficiency through the establishment of councils, coordinating bodies, and secretariats; and increasing funds for health services research in the areas of policies, utilization, and health promotion (Mhatre and Deber, 1992: 655). The provisions of health services for First Nations and Inuit, and the role of the federal government, received remarkably little attention in these reviews.

Only three provincial reports ${ }^{9}$ mentioned Indigenous health explicitly (Alberta's Rainbow Report, Government of Alberta, 1989; Québec's Commission d'enquête, Gouvernement du Québec, 1987; and British Columbia's Closer to home, British Columbia Royal Commission on Health Care and Costs, 1991). While all three provinces included descriptive information on the health of First Nations, Inuit (Québec only) and Métis (Alberta only), and may acknowledge the responsibility of the federal government, they provided little substantial direction. A notable exception was Closer to Home: The Report of the British Columbia Royal Commission on Health care and Costs report (British Columbia Royal Commission on Health Care and Costs, 1991), which contained substantial Indigenous-specific information, focussing almost exclusively on expanding care for Indigenous peoples living off-reserve in urban centres; the negotiation of agreements to fund physicians services on-reserve; and the extension of full bealth services to all communities (British Columbia Royal Commission on Health Care and Costs, 1991: C-31-C-32). Although Ontario's review did not include Indigenous-specific provisions (Government of Ontario, 1987), the province issued in 1994 what remains today the most comprehensive strategy (Ontario Minister of Health, 1994). The document opens with a letter of support from Chief Gordon B. Peters, then Ontario’s Regional Chief for the Chiefs of Ontario, and from Vera Pawis-Tabobondung, President of the Ontario Federation of

9 Reports from New Brunswick and Nova Scotia were silent on Indigenous health. Manitoba did not undertake a health system's review. Prince Edward Island was not reviewed. 
Friendship Centres. This may be the earliest example of provincial policy developed with, as opposed to for Indigenous peoples. The policy recognized the importance of traditional healers, elders and midwifes; acknowledged barriers to access to care; committed to increasing the participation of Indigenous peoples in planning; and acknowledged the need for increased clarity of federal and provincial governments' responsibilities. The policy also led to the creation of a number of provincially funded urban Indigenous health centres, managed by Indigenous boards of directors. Be that as it may, all reports side-stepped issues of federal/provincial jurisdictional disputes.

In contrast, multiple national review processes have raised the complexities surrounding Indigenous health, in some cases offered tepid solutions, but most often, limited themselves to simply naming the problem. For example, the 1994 National Forum on Health began a 3-year public consultation on health care, with the view of recommending reforms. The final report, Canada Health Action: Building on the Legacy (Government of Canada, 1998: 147-191), made a number of recommendations to ensure the sustainability of Medicare, including the preservation of its design, reinforced by greater integration of the system; investments in home care, pharmacare and primary care; investments in the health of children and families; a focus on healthy communities; and a nation-wide health information system. To address Indigenous health inequities, the report also recommended the creation of an Aboriginal Health Institute, and of the Aboriginal Health Transition Fund (AHTF), a \$50 million annual fund to pilot and evaluate evidence-based innovations. In doing so, recommendations supported community-based initiatives, side-stepping structural issues such as jurisdictional disputes. Perhaps as a result of the impetus created by the 1990 Oka crisis ${ }^{10}$ and subsequent the 1994 Royal Commission on Aboriginal Peoples (RCAP, 1996a), the National Aboriginal Health Organization was incorporated in 2000 with a mandate to conduct, improve and promote research to enhance the health and well-being of all First Nations, Inuit and Métis, and facilitate knowledge translation. While the organization was defunded in June 2012, between 2005 and 2011, the AHTF funded a total of 311 projects, the legacy of which is now unclear beyond lessons and recommendations (Dion Stout and Kipling, 2002).

While the above suggests federal and provincial support for improving Indigenous health, which translated in explicit provincial (at least in British Columbia and Ontario) and federal commitments, none addressed the structural barriers that undermine the 14th health care system. In contrast, the RCAP devoted a whole chapter on health, including recommendations focussed on federal, provincial and territorial funding and support to Indigenous health organizations, healing lodges and holistic programmes, increasing the emphasis on the determinants of health, increasing Indigenous human resources, and improving the

10 See Swain (2010) for a detailed discussion of this event. 
responsiveness of existing systems (Boyer et al., 2017). RCAP also included this important recommendation:

Governments [Federal and provincial/territorial] act promptly to conclude agreements recognizing their respective jurisdictions in areas touching directly on Aboriginal health (RCAP, 1996b, 3.3.2: 632).

This recommendation is to my knowledge the first mention of the need for formal, explicit federal-provincial agreements to finally address the jurisdictional debate.

While jurisdictional issues have been raised in previous reports (Booz Allen \& Hamilton Canada Ltd, 1969), an assumption embedded in all federal (held for at least 50 years but most likely longer) publications and in most national health care reviews on the subject was that federal funded, on-reserve health services would eventually devolve to the provinces and territories, or to Indigenous authorities (an emerging assumption). The latter was assumed to imply greater integration into provincial systems, and perhaps an eventual wholesale transfer of oversight to the provinces. In that context, clarifying the federal government's responsibilities would have been seen as irrelevant.

In 1982, an amendment to the Canadian Constitution resulted in the recognition of the inherent right to self-government for Aboriginal peoples as an existing Aboriginal right within section 35 of the Constitution Act, 1982 (Canada, 1982). This further energized discussions for increased Indigenous community control over health services while subsequent federal reports at times embraced and at others problematized this new era of community control. For example, the report of the Royal Commission on the Future of Health in Canada (also known as the Romanow Report) was released in November 2002, of which chapter 10 was dedicated to addressing Indigenous health issues. The report echoed findings from the RCAP that systemic barriers continue to undermine Indigenous peoples' ability to fully benefit from the Canadian health care systems, because of conflicting constitutional assumptions, fragmented services and inadequate access, and different cultural and political influences. Building on the above RCAP recommendation, the Commission recommended that current funding for Indigenous health services provided by all levels of governments be pooled into single consolidated budgets in each province and territory to be used to integrate Indigenous health care services, improve access, and provide adequate, stable and predictable funding. This funding, the report further proposed, was to be used to fund new Aboriginal Health Partnerships that would be responsible for developing policies, providing services and improving the health of Indigenous peoples (Romanow, 2002). The report did not tackle the thorny issue of distinction-based policies. ${ }^{11}$

11 The Assembly of First Nations (representing First Nations, the Inuit Tapiriit Kanatami (representing Inuit) and the Métis National Council (representing Métis) have rejected pan-Indigenous approaches, to ensure that the unique histories, contexts and priorities of each group are respected and reflected in policies and programmes. Pan-Indigenous partnerships are unlikely to be supported. 
In contrast, the Standing Senate Committee on Social Affairs, Science and Technology tabled The Health of Canadians - The Federal Role (the Kirby report) in October 2002, focussing its recommendations on improving the performance of the health care sector through investments in infrastructure, and the adoption of health care guarantees to monitor timely access. While the report acknowledged that Indigenous peoples are underrepresented in and underserved by the health care sector, specific recommendations focussed exclusively on strategies for increasing the supply of Indigenous health care professionals and failed to also consider the broader issues related to jurisdiction (Kirby, The Honourable Senator Michael JL, 2002). Likewise, the report of the National Advisory Committee on SARS and Public Health (2003, the Naylor report) was released in 2003. The focus of the Naylor report was admittedly not Indigenous health, an issue the committee opted to side-step entirely and leave for others to address at greater length (National Advisory Committee on SARS and Public Health, 2003: 79). This decision did not, however, prevent the committee from problematizing Indigenous control over health services, stating,

A continuing challenge in mounting appropriate responses is a recurring tension between the right and aspirations of Aboriginal peoples to greater self-determination within the Canadian federation, and the uncertain effectiveness and efficiency of reinforcing the existent pattern of separate health systems for First Nations and Inuit communities (National Advisory Committee on SARS and Public Health, 2003: 79).

Finally, the 2003 First Ministers' Accord on Health Care Renewal built on these reports and recommendations, committing provincial and territorial governments to improving access, quality and sustainability. The 10-Year Plan to Strengthen Health Care, which followed, discussed the federal government's role in service provision and funding to First Nations and Inuit. Commitments under this theme included greater collaboration with Indigenous organizations, and some investments in the on-reserve system, health promotion programs and an Early Childhood Development strategy (Government of Canada, 2004).

The Kelowna Accord was an offspring of the 10-Year Plan's commitment to greater engagement, and informed by many months of multilevel negotiations. The 18-month process exceeded simple consultations, including multiple points of contacts at the national and regional levels with First Nations, Métis and Inuit representatives (Patterson, 2006). Commitments emerging from the Kelowna Accord included significant investments in health, education, housing and economic development. The Accord also included specific First Nations, Inuit and Métis provisions (First Ministers and National Aboriginal Leaders, 2005). Although never ratified and ultimately side-stepped by the newly elected Harper government, the Kelowna Accord marked a new level of engagement between the First Ministers and the Indigenous leaders. In British Columbia, the Kelowna Accord led to the successful negotiation of the Transformative Change Accord, 
the creation of the FNHA (as previously discussed) and the transfer of FNIHB's regional responsibilities to a First Nation authority.

The 10-Year Plan expired in 2014. Canada began renegotiating a new Health Accord in the fall of 2016. By all accounts, First Ministers' discussions were difficult and failed to produce a consensus agreement. Rather, separate agreements have been secured with all provinces and territories. As in the past, and although Indigenous political organizations were given the opportunity to address the First Ministers, the agreements signed focussed exclusively on federal-provincial-territorial relations, and excluded the 14 th health care system.

\section{Missed opportunities for reconciliation}

The issue of jurisdictional confusion gained national and some international prominence following the death of Jordan Rivers Anderson, a First Nation child from Norway House who was born with a severe disability, requiring hospital care for the first 2 years of his life. When Jordan was ready to be discharged to a specialized home-based care programme, federal and provincial authorities halted his discharge while they argued on who should pay for the services needed by Jordan. Sadly Jordan passed away while still living in a hospital room and waiting for a decision to be made (The Jordan's Principle Working Group, 2015). Indigenous and non-Indigenous Canadians mobilised to create Jordan's Principle, a child-first principle named in memory of Jordan, which requires that services be provided even where jurisdiction is not clear, and that responsibilities for payment be addressed independently. While the federal and provincial governments have made strong commitments to this principle, little progress on implementation was evident when the First Nations Child \& Family Caring Society of Canada (the Caring Society hereafter) decided to take the federal government to court on this matter. The Canadian Human Rights Tribunal (CHRT) ruled in favour of the Caring Society on 26 January 2016 and two non-compliance orders have since been issued by the CHRT against the Government of Canada. To date and despite consideration financial investments, no mechanism has been created to resolve federal/provincial jurisdictional disputes for children with complex needs, and to clarify federal obligations.

The current confusion could potentially be magnified as policies shift to make space for the 2016 Supreme Court Daniels decision (Canada, 2016), which affirmed that non-status Indians and Métis are also a matter of federal responsibility. At the time of writing, this decision has yet to visibly impact federal policy or practices. It has, however, led the Government of Manitoba to end its funding to the Manitoba Métis Federation's Health and Social Directorate, an organization that was recognized nationally as a leader in Métis health research (see, e.g. Bartlett et al., 2010; Martens et al., 2010; Martens et al., 2011). The federal government has not stepped in to fill this gap. 
The 2015 Truth and Reconciliation Commission of Canada has called for a new relationship between Canada and Indigenous peoples, stating that:

By establishing a new and respectful relationship, we restore what must be restored, repair what must be repaired, and return what must be returned (Truth and Reconciliation Commission of Canada, 2015: 6).

The principles that are to underpin this new relationship call for: a recognition of Indigenous peoples' right to self-determination; constructive action on addressing the on-going legacies of colonialism; working towards a more equitable and inclusive society; respect for Indigenous knowledge systems and their guardians; 'political will, joint leadership, trust building, accountability, and transparency; as well as a substantial investment of resources' (Truth and Reconciliation Commission, 2015: 3-4).

So, while the federal government promotes reconciliation, it continues to claim that its involvement in the funding and delivery of First Nation and Inuit health services is on humanitarian grounds alone. And while great efforts were made by the federal government over decades to curtail (and perhaps end) its involvement, it nevertheless continues. The federal government's refusal to acknowledge and name its responsibilities perpetuates barriers to care borne from confusion and overt denial of services.

While First Nations, Inuit and Métis organizations have been invited to address the First Ministers to present on their specific needs, they have once again been excluded from the actual Accord negotiation process. This is regrettable. As a unique instrument of cross-jurisdictional coordination, Health Accords should include four key components:

1. a more explicit commitment to First Nations, Métis and Inuit health equity that includes yearly reporting on progress;

2. clarity over jurisdictional federal/provincial/territorial obligations, including an explicit statement of federal obligations that could be used for accountability purposes;

3. effective mechanisms for addressing areas of federal/provincial/territorial/first Nations/Inuit jurisdictional dispute and/or confusion; and

4. an explicit recognition that First Nations and Inuit nations health care services as integral yet distinct systems, that nevertheless must be supported to seamlessly work with provincial/jurisdictional health care systems to ensure continuity of care.

\section{Conclusions}

In conclusion, the persistence of the 14th health care system has been fuelled by repeated commitments to Indigenous self-determination and control over their health services. Current trends indicate a continued role for the federal government, this despite repeated attempts at ending or limiting this role. Indeed, a unilateral transfer of responsibilities, including the funding and oversight of this system to the 
provinces or territories, seems very unlikely in the near or intermediate future, and would likely result in a substantial Indigenous push back and world-wide criticisms. It is time to end the myth of the unwritten turning off the light federal policy, explicitly acknowledge responsibilities, implement mechanisms to address long-standing challenges including jurisdictional disputes and confusion, and welcome the 14th health care system as an equal partners with its 13 other counterparts. The status quo is perpetuating inequities, misery and associated higher health care costs. The time for fundamental health policy renewal to address these issues is long overdue.

\section{Acknowledgement}

The Associated Medical Services (AMS Healthcare) has a long and impressive history as a catalyst for change in healthcare. I would like to thank Anne Avery, Gregory Marchildon and Collen Flood for inviting me to contribute to AMS Healthcare's 80th anniversary celebration, by providing a paper and presenting it to the AMS annual conference in June 2017. To those who provided feedback at the conference, and to an earlier version of this paper, many thanks for your thoughtful insights. The final paper was much improved as a result.

\section{References}

Auditor General of Canada (1982), 'Department of National Health and Welfare'. Auditor General of Canada. Office of the Auditor General of Canada, Ottawa.

Auditor General of Canada (2015), 'Report 7, establishing the First Nations Health Authority in British Columbia', Office of the Auditor General of Canada, Ottawa.

Barron, F. L. (1997), Walking in Indian Mocassins: The Native Policies of Tommy Douglas and the CCF, Vancouver, BC: UBC Press.

Bartlett, J. G., J. Sanguins, S. Carter, N. Hoeppner and P. Mehta (2010), Diabetes and Related Health Care Utilization in the Metis Population in Manitoba, Winnipeg, MB: Manitoba Metis Federation.

Bégin, The Honourable Monique (1981), 'Discussion paper: transfer of health services to Indian communities', Ottawa.

Booz Allen \& Hamilton Canada Ltd (1969), Study of Health Services for Canadian Indians, Ottawa: Booz Allen \& Hamilton Canada Ltd .

Boyer, Y. (2004), 'The International Right to Health for Indigenous Peoples in Canada'. Discussion Paper Series on Aboriginal Health, Legal Issues: No. 3, National Aboriginal Health Organization, Ottawa.

Boyer, Y. (2014), Moving Aboriginal Health Forward: Discarding Canada's Legal Barriers, Saskatoon, SK: Purich Publishing Ltd.

Boyer, Y., J. G. Lavoie, D. Kornelsen and J. Reading. (2017), '20 Years later: RCAP's legacy in Indigenous health system's governance - What about the next twenty?', RCAP 20 Forum, Winnipeg, MB.

British Columbia Provincial Health Officer (2009), 'Pathways to health and healing 2nd report on the health and well-being of Aboriginal people in British Columbia', Provincial Health Officer's Annual Report 2007, Victoria, BC. 
British Columbia Royal Commission on Health Care and Costs (1991), 'Closer to home: the report of the British Columbia Royal Commission on health care and costs', Victoria, BC.

Brittain, W. B. (1959), 'The impact of hospital insurance on Indian Health Services', Medical Services Journal, 15: 632-634.

Canada (1974), The James Bay and Northern Quebec Agreement (JBNQA), Ottawa: Government of Canada.

Canada (1982), 'The Constitution Act', 1982, being Schedule B to the Canada Act 1982 (U.K.), 1982 , c. 11.

Canada (1985), 'Indian Act (R.S., 1985, c. I-5)'. http://canlii.ca/t/52fln> [12 November 2017].

Canada (2004), 'Canada Health Act', RSC 1985, c C-6, http://canlii.ca/t/51w33 [12 November 2017].

Canada (2016), 'Daniels v. Canada (Indian Affairs and Northern Development): Supreme Court Judgments'. Supreme Court Judgments, Ottawa.

Carrière, G., E. Bougie, D. Kohen, M. Rotermann and C. Sanmartin (2016), Acute Care Hospitalization by Aboriginal Identity, Canada, 2006 Through 2008, Ottawa: Statistics Canada.

Crombie, The Honourable David (1979), 'Statement on Indian Health Policy'. Ottawa.

Dacks, G. (1990), Devolution and Constitutional Development in the Canadian North, Ottawa: Carleton University Press. (Reprint, Not in File).

Dion Stout, M. and G. D. Kipling (2002), Sharing the Learning: The Health Transition Fund, Synthesis Series, Aboriginal Health, Ottawa: Health Canada.

First Ministers and National Aboriginal Leaders (2005), 'Strengthening relationships and closing the gap, Kelowna, British Columbia', 24-25 November, Government of Canada, Ottawa.

First Nations Health Council, Government of Canada, and Government of British Columbia (2010), 'British Columbia Tripartite First Nations Health: basis for a framework agreement on health governance', Victoria, BC.

Gallagher, J., J. K. Mendez and T. Kehoe (2015), 'The First Nations Health Authority: a transformation in healthcare for BC First Nations', Healthcare Management Forum, 28(6): 255-261.

Gouvernement du Québec (1987), 'Commission d'enquête sur les services de santé et les services sociaux', Gouvernement du Québec, Québec.

Government of Alberta (1989), 'The Rainbow Report, Volume II, Premier's Commission on Future Health Care for Albertans', Government of Alberta, Edmonton, AB.

Government of Canada (1998), 'Canada health action: building on the legacy - Volume I - the Final Report', Government of Canada, Ottawa.

Government of Canada (2004), 'First Ministers' Meeting on the Future of Health Care: a 10 year plan to strengthen health care', Government of Canada, Ottawa.

Government of Ontario (1987), 'Towards a shared directions for health in Ontario', Government of Ontario, Toronto, ON.

Health Canada (FNIHB) (2008a), 'Contribution funding framework and agreement modification', Ottawa.

Health Canada (FNIHB) (2008b), 'Transfer status as of March 2008', Ottawa.

Health Canada (MSB) (1995), 'Pathways to First Nation control, report of project 07, strategic planning exercise', 1995 Final Report, Ottawa.

Higgins, J. (2009), 'Aboriginal people and confederation', Newfoundland and Labrador Heritage, St John’s, NL. 
The Jordan's Principle Working Group (2015), 'Without denial, delay, or disruption: ensuring First Nations children's access to equitable services through Jordan's Principle', Assembly of First Nations, Ottawa.

Kelly, M. D. (2011), 'Toward a new era of policy: health care service delivery to First Nations', The International Indigenous Policy Journal, 2(1): 1-12.

Kirby, The Honourable Senator Michael JL (2002), 'The health of Canadians - the federal role', Ottawa.

Lavoie, J. G. (2016), 'A comparative financial analysis of the 2003-04 and 2009-10 health care expenditures for First Nations in Manitoba', Unpublished Manuscript, MFN-Centre for Aboriginal Health Research, Winnipeg, MB.

Lavoie, J. G., D. Kornelsen, Y. Boyer and L. Wylie (2016a), 'Lost in maps: regionalization and Indigenous health services', HealthcarePapers, 16(1): 63-73.

Lavoie, J. G., J. M. Kaufert, A. Browne and J. D. O’Neil (2016b), 'Managing Matajoosh: determinants of First Nations' cancer care decisions', BMC Health Services Research, 16(402): 1-12.

Lavoie, J. G., L. Gervais, J. Toner, O. Bergeron and G. Thomas (2013), 'Aboriginal health policies in Canada: the policy synthesis project', Prince George, BC.

Lavoie, J. G., M. K. Joseph, A. J. Browne, S. Mah and J. D. O’Neil (2015), 'Negotiating barriers, navigating the maze: First Nation peoples' experience of medical relocation', Canadian Public Administration, 58(2): p. 295-314.

Lavoie, J. G., E. L. Forget, T. Prakash, M. Dahl, P. J. Martens and J. D. O’Neil (2010), 'Have investments in on-reserve health services and initiatives promoting community control improved First Nations' health in Manitoba?', Social Science and Medicine, 71(4): 717-724.

Lavoie, J. G., J. O’Neil, L. Sanderson, B. Elias, J. Mignone, J. Bartlett, E. Forget, R. Burton, C. Schmeichel and D. MacNeil (2005), 'The evaluation of the First Nations and Inuit Health Transfer Policy', Winnipeg, MB.

Lux, M. K. (2010), 'Care for the "racially careless": Indian hospitals in the Canadian West, 1920-1950s', Canadian Historical Review, 91(3): 407-434.

Lux, M. K. (2016), Separate Beds: A History of Indian Hospitals in Canada, 1920s-1980s, Toronto, ON: University of Toronto Press.

Madore, Odette (1991), 'Established programs financing for health care', Government of Canada, Economic Division, BP-264-E, Ottawa.

Martens, P. J., J. G. Bartlett, H. J. Prior, J. Sanguins, C. A. Burchill, E. M. Burland and S. Carter (2011), 'What is the comparative health status and associated risk factors for the Metis? A population-based study in Manitoba, Canada', BMC Public Health, 11: 814.

Martens, P. J., J. Bartlett, E. Burland, H. Prior, C. Burchill, S. Huq, L. Romphf, J. Sanguin and A. Bailly (2010), 'Profile of Metis health status and healthcare utilization in Manitoba: a population-based study', Winnipeg, MB.

Mhatre, S. L. and R. B. Deber (1992), 'From equal access to health care to equitable access to health: a review of Canadian health commissions and reports', International Journal of Health Services, 22(4): 645-668.

National Advisory Committee on SARS and Public Health (2003), Learning from SARS Renewal of Public Health in Canada, A report of the National Advisory Committee on SARS and Public Health October 2003. Ottawa.

O’Neil, J., J. Gallagher, L. Wylie, B. Bingham, J. G. Lavoie, D. Alcock and H. Johnson (2016), 'Transforming First Nations' health governance in British Columbia', International Journal of Health Governance, 21(4): 229-244.

Ontario Minister of Health (1994), New Directions: Aboriginal Health Policy for Ontario, Toronto, ON: Ministry of Health. 
Patterson, L. L. (2006), 'Aboriginal roundtable to Kelowna Accord: Aboriginal policy negotiations, 2004-2005', Political and Social Affairs Division, Parliamentary Information and Research Service, Library of Parliament, Ottawa.

Romanow, C. R. J. (2002), 'Building on values, the future of health care in Canada', Final Report, Ottawa.

Royal Commission on Aboriginal Peoples (RCAP) (1996a), 'People to people, nation to nation: highlights from the Report of the Royal Commission on Aboriginal Peoples', Minister of Supply and Services Canada, Ottawa.

Royal Commission on Aboriginal Peoples (RCAP) (1996b), 'Volume 5 - a twenty year commitment', Ottawa.

Shah, B. R., N. Gunraj and J. E. Hux (2003), 'Markers of access to and quality of primary care for Aboriginal People in Ontario, Canada', American Journal of Public Health, 93(5): 798-802.

Stevenson, H. M., A. P. Williams and E. Vayda (1988), 'Medical politics and Canadian Medicare: professional response to the Canada Health Act', Milbank Q, 66(1): 65-104.

Swain, H. (2010), Oka: A Political Crisis and its Legacy, Madeira Park, BC: D \& M Publishers.

Titley, E. B. (2009), The Indian Commissioners: Agents of the State and Indian Policy in Canada's Prairie West, 1873-1932, Edmonton, AB: University of Alberta Press.

Truth and Reconciliation Commission (2015), What We Have Learned: Principles of Truth and Reconciliation, Ottawa: Truth and Reconciliation Commission of Canada.

Truth and Reconciliation Commission of Canada (2015), Honouring the Truth, Reconciling for the Future Summary of the Final Report of the Truth and Reconciliation Commission of Canada, Ottawa: Truth and Reconciliation Commission of Canada.

Waldram, J. B., D. A. Herring and T. K. Young (2006), Aboriginal Health in Canada: Historical, Cultural and Epidemiological Perspectives, 2nd edn, Toronto, ON: University of Toronto Press.

Weaver, S. (1971), 'Smallpox and chickenpox: an Iroquoian community's reaction to crisis, 1901-1902', Ethnohistory, 18: 361-378. 